\title{
GDP and Tax Revenues-Causality Relationship in Developing Countries: Evidence from Palestine
}

\author{
Raed A. M. Iriqat ${ }^{1} \&$ Ahmad N. H. Anabtawi ${ }^{2}$ \\ ${ }^{1}$ Department of Business Administration, Faculty of Administrative and Financial Sciences, The Arab American \\ University, Palestine \\ ${ }^{2}$ Department of Accounting, Faculty of Administrative and Financial Sciences, The Arab American University, \\ Palestine \\ Correspondence: Raed A. M. Iriqat, Department of Business Administration, Faculty of Administrative and \\ Financial Sciences, The Arab American University, P. O. BOX 240, Jenin-West Bank, Palestine. Tel: \\ 970-595-386-355. E- mail: raed.iriqat@aauj.edu
}

Received: January 10, 2016

Accepted: January 29, 2016

Online Published: March 25, 2016

doi:10.5539/ijef.v8n4p54

URL: http://dx.doi.org/10.5539/ijef.v8n4p54

\begin{abstract}
The study aims to investigate the causality relationship between Gross Domestic Product and its components with Tax revenues in developing countries as a case study in Palestine. This study based on an empirical approach using secondary data from Palestine monetary Authority during (1999-2014). The findings exposed mainly that the tax revenues does not Granger Cause each of the Palestinian Gross Domestic Product, Government spending, Consumption, Investment and Balance of trade. In addition, researcher divided period of study into three stages according to changing in income tax act. Moreover, results shows that the impact of macro-economic variables on tax revenues and correlations between dependent and independent variables was changing from one stage to other.

This paper concludes that the Palestinian authority should motivate investment conditions and improve the tax collection instruments and decrease the tax invasion. In addition, Palestinian government should rationalize the government consumption spending and increase the government expenditure for the development.
\end{abstract}

Keywords: tax revenues, gross domestic product, government spending, consumption, investment and balance of trade

\section{Introduction}

Tax is an important fiscal policy for the states and its economy. The developed countries aim of the fiscal policy is to achieve the economic stability. However, the developing countries use taxes to achieve the economic development. The governments use taxes to raise the economic and productive efficiency of the state, by monitoring the economic resources and to exploit these recourses in full (Hijazi, 2001). In addition, the fiscal policy of the state supports the stability of the economy and determines the economic policies the tax legislations effect the economy through the influence on the investment, consumption, saving, employment and inflation (AL-Mahaeni, 2003). Meswadi and Almufleh (2015), a research base on Jordan, finds the tax revenues in Jordan contributed to raise the Jordanian general budget more than the non-tax revenues and donations.

The British Mandate imposed income tax, for the first time in Palestine, in 1941, under law no. 23 of 1941. It was amended in 1947; law no. 113 of 1974. After the Nakba war in 1948, the temporary law no. 50 of 1951 is completed, then law no. 12 of 1954. It was applied in the West Bank, but the applied law in Gaza Strip remained as it. In 1964 the tax law no. 25 issued, which added substantial amendments of the concept of income (Likhovski, 2010). After the Israeli occupation in 1967, the taxes remained as it until 1975, when many of the tax laws is added for the value-added tax law in 1975; beside the amendment at the progressive income tax from 5.5\% to 55\%, and at the profits of the joint stock companies in the West Bank to 38.5\% and in Gaza Strip to 37.5\%

In 1993, Palestinian Liberation Organization signed Oslo Agreement with the Israeli side, which emanated Paris economic Convention from it in 1994. Through it, he powers of taxation transferred the Palestinian Authority, which, in turn, modified and reduced the income tax rates. While they kept working under law no. 25 of 1964, until they issued law no. 17 in 2004 which started in 2005. (Rahhal, 2014) Income Tax Act is amended many 
times between 2005 and 2015. The most prominent amendment were at tax slides, tax exemptions, increase in the rates and amounts of some of the expenses which are excepted for the tax purposes, as well as the changing of the legal currency of the US dollar to the Israeli Shekel, and others.

It should be noted that Paris Convention gave Israel the right of levy taxes on the exported and imported goods, to compete the Palestinian Authority, which caused an economic problem because of the Israeli control at the tax revenue of the Palestinian Authority.

According to MAS, 2015, the tax code in the Palestinian authority has been modified since 2004 to 2015 . The first modification took place at 2004, second in 2007 and last 2011. However, in 2014 another modification arisen related to the investment income and interest exemption. Thereafter, in May, 2015 the most recent modification announced by the Palestinian authority.

This paper divides the time series of the study from 1999-2015 into three stages. From 1999-2007, from 2008-2010 and from 2011-2014. The tax modifications in 2007 and 2011 were crucial, nevertheless, it will be considered as remarkable stages within the time series in this paper. These stages classified base on the researchers' believe that it has a major changes and modifications in tax codes labeled to each one of the above stages.

The main purpose of this paper is to explore the impact of GDP and its components on tax revenues in Palestine over the time period1999-2014. From the main purpose of this paper, following sub-objectives have been derived.

- To investigate the impact of GDP on tax revenues in Palestine.

- To investigate the impact of GDP components on tax revenues in Palestine.

This paper consists of six sections as in the following: section (1) an introduction, section (2) the literature review, section (3) describes the hypotheses of the study, section (4) addresses methodology, section (5) presents the results and section (6) reports the conclusion and recommendations.

\section{Literature Review}

In this section, we demonstrate recent studies, which are related to impact tax revenues on GDP and its components (Government spending, consumption, investment and balance of trade). This section aims to allow the comparison between this paper's findings and the previous literature to make a conclusion.

Many studies argue the relationship between tax policy and the economic growth and how it could affect each one other. (Chigbu et al., 2012) examine the relationship between tax revenue and economy in Nigeria. (Muibi \& Sinbo, 2013) analyze the level of economic growth that has impacted positively on tax revenue in Nigeria. The general conclusion is that macroeconomic instability and degree of economic activities are the main drivers of tax buoyancy and tax effort in Nigeria. The paper found that taxation is an important instrument to improve economic growth. (Canicio \& Zachary, 2014) show that there is an independence between the economic growth and government tax revenues. The study finds that $30 \%$ speedier relationship of adjustment in the short run towards equilibrium level in the long run. (Brender \& Navon, 2010) aim to test the relation of the GDP with tax revenues. The paper studies the uncertainty in predicting the tax revenue in Israel. The study shows that the long-run tax-revenue and GDP are elastic. (Hakim \& Bujang, 2012) sate that the statistical evidence suggests that the total tax revenue to GDP ratio is higher in the high income countries compared with the low and middle countries. In addition to that (Mashkoor et al., 2010) show that saving causes the real GDP growth unidirectional and the direct tax to GDP ratio granger causes the real GDP growth significantly.

Government spending and tax revenues have been tested by several studies. Hafiz, 2006 points out those tax revenues are very important to underpin the general budget to cover public expenditures (Miswadeh \& Al-Mofleh, 2015). In addition, taxes is considered the main motive to control the economic activities. (Hussien, 2005; Nanthakumar et al., 2011; Taha et al., 2008) find a causality between government expenditure and tax revenues in there testing models. (Zortuk \& Uzgoren, 2008) study the causality and long-run relationship between the government spending and tax revenues in oil exporting countries during 2000-2009 period. The study finds that the short-run and long-run government spending has a positive impact on taxation. Another study finds bidirectional causality between taxes and expenditures in five of G7 countries (Owoye, 1994). However, (Al-Khulaifi, 2012) and (Mehrar \& Rezaei, 2014) find unidirectional causality running from government revenues to government expenditure.

For the analysis of relationship between investment as an important element of GDP and tax revenues, many researchers test the relationship between investment and tax. Gentry and Hubbard (2000) provide evidence that 
the progressive personal tax rate discourage risk taking. While Gordon (1998) finds low corporate tax rates encourage risk taking. Mahmood (2013) studies the impact of FDI and tax returns in Pakistan. The study considers the FDI and the GDP per capita in Pakistan. They find out a long run and short run relationships exist in the tax revenue model for both FDI and GDP per capita. Tzougaz (2013) examines the data related to tax revenues, private investment and real income for the period 1980-2011 using Granger causality tests. The study finds a short-run and long-run positive relationship between investment and tax revenues.

Another important element of macroeconomics is the consumption which is a part of this study to examine the relationship with tax revenues. (Aquash \& Ojong, 2014) show that all the revenue allocations and generation in the local government council were inflexible (inelastic) with respect to consumption (VAT). Consumption considered as a major source of revenue generation for tax revenues and that more revenue could be generated with increase in consumption tax, than with decrease in consumption tax. Miki (2011) finds the results of regression show that the trend of aggregate consumption and real GDP growth per capita when the VAT rate is raised.

The last factor of this study is the balance of trade and its relationship with tax revenues. In this regard Slemrod (2004) observes for 100 countries at different income levels in four years focusing on net exports and on the potential dynamics of tax effects. The research finds a significant positive association between corporate tax revenues to GDP and trade intensity. Li and Murphy (2010), finds the remarkable fall in imports could be an important consideration when explaining the fall in tax-revenue-to-GDP ratios that were observed in 2009, because in many countries, imports are a key component of the tax base. Thus, the paper finds that when import accelerates, tax revenues decline. Agbeyegbe et al. (2004) investigated the relationship between the tax revenue, trade liberalization and changes in the exchange rate. The paper suggests that trade liberalization and terms of trade exert have positively affected the total tax revenue.

\section{Hypotheses of the Study}

There is no interdependence among Palestinian tax revenues due to the GDP components. This hypothesis consists of five sub-hypotheses, which are:

(H1-1): The Palestinian tax revenues do not Granger Cause the Palestinian GDP.

(H1-2): The Palestinian tax revenues do not Granger Cause the Palestinian Government spending.

(H1-3): The Palestinian tax revenues do not Granger Cause the Palestinian consumption.

(H1-4): The Palestinian tax revenues do not Granger Cause the Palestinian Investment.

(H1-5): The Palestinian tax revenues do not Granger Cause the Palestinian Balance of Trade.

\section{Methodology}

\subsection{Sources of Data}

In this paper, the researchers uses the secondary data were published in the annual report- Palestine monetary Authority in 2008, 2013 and 2014. The time series data covered the time period from 1999 to 2014. The tax revenues are the independent variable, whereas the five selected variables which are classified as components of economic growth are independent variables (GDP, government expenditure, consumption, investment and balance of trade).

\subsection{Econometric Models}

Table 1 below shows the OLS models. The model represents the five macroeconomic variables (GDP and it four components) and its influence on tax revenues. The table shows the detailed sub-hypothesis models by defining independent and dependent variables.

Table 1. The OLS models for testing hypothesis

\begin{tabular}{llc}
\hline Sub-hypothesis & Model & Model \# \\
\hline (H1-1): The Palestinian tax revenues does not Granger Cause the Palestinian GDP & $T R_{p t}=a_{0}+a_{1} G D P_{p t}+\mathrm{e}$ & $(1)$ \\
(H1-2): The Palestinian tax revenues does not Granger Cause the Palestinian Government & $T R_{p t}=b_{0}+b_{1} G S_{p t}+\mathrm{e}$ \\
spending. & $T R_{p t}=c_{0}+c_{1} C_{p t}+\mathrm{e}$ \\
(H1-3): The Palestinian tax revenues does not Granger Cause the Palestinian consumption & $T R_{j t}=d_{0}+d_{1} I_{p t}+\mathrm{e}$ \\
(H1-5): The Palestinian tax revenues does not Granger Cause the Palestinian investment. & $T R_{p t}=e_{0}+e_{1} B T_{p t}+e$ \\
(H1-4): The Palestinian tax revenues does not Granger Cause the Palestinian Balance of Trade & $(5)$ \\
\hline
\end{tabular}


Where:

$\mathrm{TR}_{\mathrm{Pt}}$ : The Palestinian tax revenues for the period $\mathrm{t}$.

$\mathrm{GDP}_{\mathrm{Pt}}$ : The Palestinian gross domestic product for the period $\mathrm{t}$.

$\mathrm{GS}_{\mathrm{Pt}}$ : The Palestinian governmental spending for the period $\mathrm{t}$.

$\mathrm{C}_{\mathrm{Pt}}$ : The Palestinian consumption for the period t.

$\mathrm{I}_{\mathrm{Pt}}$ : The Palestinian investment for the period $t$.

$\mathrm{BT}_{\mathrm{Pt}}$ : The Palestinian balance of trade for the period $\mathrm{t}$.

$\mathrm{a}_{0}, \mathrm{~b}_{0}, \mathrm{c}_{0}, \mathrm{~d}_{0}, \mathrm{e}_{0}$ : Constants.

$a_{1}, b_{1}, c_{1}, d_{1}, e_{1}$ : The independent variables coefficient.

e: error

\section{The Results}

\subsection{Descriptive Analysis}

Table 2shows the descriptive statistics of the macroeconomics variables used in this study. The time series covers 16 years of time from 1999-2014. It also represents the mathematical mean, standard deviation, maximum value and minimum value for each variable. It is clear from Table 2 that all macroeconomic variables are significantly changed in the time interval. Moreover, the large difference between maximum and minimum values is explained by the large standard deviation for each variable. This prove that the economic environment in Palestinian Authority is instable.

Table 2. Descriptive statistics of dependent and independent variables (1999-2014)

\begin{tabular}{lcccc}
\hline Macroeconomic Variables & Mean & Standard Deviation & Max Value & Min Value \\
\hline Tax revenues & 703 & 388.62 & 1520 & 183 \\
Gross Domestic Product & 5182.45 & 1316.69 & 7449 & 3156 \\
Government spending & 1777.063 & 593.98 & 2840 & 821 \\
Consumption & 6027.888 & 1087.05 & 7772.7 & 4067 \\
Investment & 1110.544 & 271.4 & 1898 & 776 \\
Balance of Trade & -2709.019 & 436.68 & -2070 & -3794 \\
\hline
\end{tabular}

\subsection{Testing the Normality}

Table 3 shows that the null hypothesis (X variable follows the normal distribution) should be accepted for all variables except the investment where Alpha value is less than .05. Nevertheless, Pearson correlation test, simple linear regression, and the Granger causality test are the parametric tests are used in this research.

Table 3. The results of Jarque-Bera normality test

\begin{tabular}{lcc}
\hline Macroeconomic indicators & Jarque-Bera Coefficient & Probability \\
\hline Tax revenues & 1.474211 & 0.478497 \\
GDP & 1.060282 & 0588522 \\
Government spending & 0.922098 & 0.630622 \\
Consumption & 0.475412 & 0.788434 \\
Investment & 10.40689 & 0.005498 \\
Balance of Trade & 1.090672 & 0.579647 \\
\hline
\end{tabular}

\subsection{Empirical Results}

In this section of the study, the researchers divide the time intervals into three stages. The stages classified due to the changes in income tax brackets in Palestinian Authority in these stages. First stage from 1999 to 2007, second stage from 2008-2010 and the last stage from 2011 to 2014. This research tests the person correlation and OLS regression for each of the above stages to investigate if the changes within each stage would affect the relationships between macroeconomic variables and tax revenues.

5.3.1 First Stage: 1999 to 2007

Table 4 represents the Person correlation coefficient between dependent and independent variables in first 
interval 1999-2007.Findings in below table indicate a significant strong positive relationship between tax revenues and each of GDP, government spending and consumption $(r=.843, p<0.01, r=.779, p<0.05, r=.848$, $\mathrm{p}<0.01)$ respectively. Whereas, it represents a significant strong negative relationship between tax revenues and balance of trade $(r=-.838, \mathrm{p}<0.01)$. Secondly, the balance of trade is negatively correlated to all independent variables (GDP, government spending and consumption) except investment $(\mathrm{r}=-.881, \mathrm{p}<0.01, \mathrm{r}=-.804, \mathrm{p}<0.01$, $\mathrm{r}=-.943, \mathrm{p}<0.01)$. Thirdly, there is a significant strong positive relationship between GDP and each of government spending and consumption $(\mathrm{r}=.862, \mathrm{p}<0.01, \mathrm{r}=.958, \mathrm{p}<0.01)$ respectively. In addition, there is a significant positive relationship between government spending and consumption $(\mathrm{r}=.751, \mathrm{p}<0.05)$.

Table 4. Correlation coefficient among dependent and independent variables 1999-2007

\begin{tabular}{|c|c|c|c|c|c|c|}
\hline Variables & 1 & 2 & 3 & 4 & 5 & 6 \\
\hline Tax revenues & 1 & $.843^{* *}$ & $.779^{*}$ & $.848^{* *}$ & .268 & $-.838^{* * *}$ \\
\hline GDP & & 1 & $.862^{* *}$ & $.958^{* *}$ & .371 & $-.881 * *$ \\
\hline Government spending & & & 1 & $.751^{*}$ & -.086 & $-.804 * *$ \\
\hline Consumption & & & & 1 & .551 & $-.943 * *$ \\
\hline Investment & & & & & 1 & -.423 \\
\hline Balance of Trade & & & & & & 1 \\
\hline
\end{tabular}

Table 5illustrates the influence of independent variables on tax revenues in separated models using OLS method. The linear- regression hypothesis empirically confirm that each one of the Palestinian GDP, government spending and consumption has a significant positive effect on tax revenues. Whereas, it confirms that Palestinian balance of trade has a significant negative effect on tax revenues in Palestinian authority for the period from 1999-2007.Moreover, the equations (1), (2) and (3) show that the positive impact of GDP, government spending and consumption on tax revenues is significant with (p- value) less than 0.05 and with coefficients $0.570,0.941$ and 0.530 respectively. Equation (4), however, shows the negative impact for balance of trade on tax revenues with p- value of 0.05 and with coefficient of -0.948 .

Table 5. The OLS summary statistics of the Null hypothesis (the interdependence between economies according to the TAX) in the first stage1999-2007

\begin{tabular}{lccccc}
\hline \multicolumn{1}{c}{ Causal Relationship } & Constant & Coefficient & F-Value & R Square & Sig. \\
\hline Tax revenues - GDP & $\mathbf{- 1 6 3 1 . 9 1 4}$ & $\mathbf{0 . 5 7 0}$ & $\mathbf{1 7 . 2 3 5}$ & $\mathbf{0 . 7 1 1}$ & $\mathbf{0 . 0 4}$ \\
Tax revenues - GS & $\mathbf{- 6 7 0 . 6 8 3}$ & $\mathbf{0 . 9 4 1}$ & $\mathbf{1 0 . 8 0 3}$ & $\mathbf{0 . 6 0 7}$ & $\mathbf{0 . 0 1 3}$ \\
Tax revenues - C & $\mathbf{- 2 0 3 4 . 4 6 3}$ & $\mathbf{0 . 5 3 0}$ & $\mathbf{1 7 . 9 4 1}$ & $\mathbf{0 . 7 1 9}$ & $\mathbf{0 . 0 4}$ \\
Tax revenues - I & 421.607 & 0.316 & 0.541 & 0.072 & 0.486 \\
Tax revenues - BT & $\mathbf{- 1 7 3 3 . 4 2 9}$ & $\mathbf{- 0 . 9 4 8}$ & $\mathbf{1 6 . 4 7 2}$ & $\mathbf{0 . 7 0 2}$ & $\mathbf{0 . 0 5}$ \\
\hline
\end{tabular}

$$
\begin{gathered}
T R_{p t}=-1631.914+0.570 G D P_{p t}+0.537 \\
T R_{p t}=-670.683+0.941 G S_{p}+0.627 \\
T R_{p t}=-2034.463+0.530 C_{p t}+0.530 \\
T R_{p t}=-1733.429-0.948 B T_{p t}+0.549
\end{gathered}
$$

equation(4)

\subsubsection{Second Stage: 2008-2010}

Table 6 represents the Person correlation coefficient between dependent and independent variables in the second stage between2008-2010.It shows that tax revenues and government spending are completely correlated in same direction $(\mathrm{r}=.999, \mathrm{p}<0.01)$.

Table 6. Correlation coefficient among dependent and independent variables 2008-2010

\begin{tabular}{lcccccc}
\hline Variables & $\mathbf{1}$ & $\mathbf{2}$ & $\mathbf{3}$ & $\mathbf{4}$ & $\mathbf{5}$ & $\mathbf{6}$ \\
\hline Tax revenues & 1 & .969 & $\mathbf{. 9 9 9}^{*}$ & .977 & .896 & -.921 \\
GDP & & 1 & .954 & .892 & .757 & -.794 \\
Government spending & & & 1 & .987 & .918 & -.940 \\
Consumption & & & & 1 & .970 & -.983 \\
\hline
\end{tabular}




\begin{tabular}{|c|c|c|}
\hline Investment & 1 & $-.998 *$ \\
\hline Balance of Trade & & 1 \\
\hline
\end{tabular}

Table 7 shows that the influence of government spending on tax revenues in Palestinian authority in period 2008-2010 is empirically confirmed. For other independent variables, there is no significant impact of all variables on tax revenues. Equation (5), furthermore, proves that the positive impact of government spending on tax revenues is significant with ( $\mathrm{p}$ - value) less than 0.05 and high value of $\mathrm{R}$ square.

Table 7. The OLS summary statistics of the Null hypothesis (the interdependence between economies according to the TAX) in the second stage 2008-2010

\begin{tabular}{lccccc}
\hline \multicolumn{1}{c}{ Causal Relationship } & Constant & Coefficient & F-Value & R Square & Sig. \\
\hline Tax revenues - GDP & -4616.628 & 0.919 & 15.134 & 0.938 & 0.160 \\
Tax revenues - GS & $\mathbf{- 1 2 1 7 . 2 4 8}$ & $\mathbf{0 . 9 2 6}$ & $\mathbf{3 6 3 . 0 3 9}$ & $\mathbf{0 . 9 9 7}$ & $\mathbf{0 . 0 3 3}$ \\
Tax revenues - C & -4121.272 & 0.742 & 20.602 & 0.954 & 0.138 \\
Tax revenues - I & -7459.1 & 7.087 & 4.066 & 0.803 & 0.293 \\
Tax revenues - BT & -1121.484 & -0.649 & 5.556 & 0.847 & 0.255 \\
\hline
\end{tabular}

$$
T R_{p t}=1217.248+0.926 G S_{p t}+0.048
$$

equation(5)

\subsubsection{Third Stage: 2011-2014}

Table 8 represents the Person correlation coefficient between dependent and independent variables in third stage between 2011-2014. In third stage of this study, Person correlation test shows that there is no relationship between tax revenues and all independent variables. Moreover, there is no significant correlation between independent variables (GDP, government spending, consumption, investment and balance of trade).

Table 8. Correlation coefficient among dependent and independent variables 2011-2014

\begin{tabular}{lcccccc}
\hline Variables & $\mathbf{1}$ & $\mathbf{2}$ & $\mathbf{3}$ & $\mathbf{4}$ & $\mathbf{5}$ & $\mathbf{6}$ \\
\hline Tax revenues & 1 & .818 & .676 & .631 & .419 & -.298 \\
GDP & & 1 & .274 & .923 & .758 & -.698 \\
Government spending & & & 1 & -.093 & .237 & .479 \\
Consumption & & & 1 & .602 & -.917 \\
Investment & & & & 1 & -.402 \\
Balance of Trade & & & & & 1 \\
\hline
\end{tabular}

**. Correlation is significant at the 0.01 level (2-tailed).

Table 9 shows the impact of independent variables on tax revenues. The null hypothesis of linear impact for each of (GDP, government spending, consumption, investment and balance of trade) is tested but it is not empirically prove that $\mathrm{p}$ - value is more than 0.05 .

Table 9. The OLS summary statistics of the Null hypothesis (the interdependence between economies according to the TAX) in the third stage 2011-2014

\begin{tabular}{lccccc}
\hline Causal Relationship & Constant & Coefficient & F-Value & R Square & Sig. \\
\hline Tax revenues - GDP & 450.852 & 0.065 & 4.041 & 0.669 & 0.182 \\
Tax revenues - GS & 428.979 & 0.054 & 1.681 & 0.457 & 0.324 \\
Tax revenues - C & -139.817 & 0.093 & 1.325 & 0.398 & 0.369 \\
Tax revenues - I & 345.33 & 0.268 & 0.425 & 0.175 & 0.581 \\
Tax revenues - BT & 334.966 & -0.075 & 0.194 & 0.089 & 0.702 \\
\hline
\end{tabular}

\subsubsection{Overall Period 1999-2014}

Table 10 represents the Person correlation coefficient between dependent and independent variables in time series between1999-2014. According to the Table 10, the tax revenues is found to be negatively related to balance of trade $(\mathrm{r}=-0.752, \mathrm{p}<0.01)$. Another negative correlation between consumption and balance of trade 
where $(\mathrm{r}=-0.630, \mathrm{p}<0.01)$. Table $(10)$ also shows GDP is positively correlated to government spending and consumption $((\mathrm{r}=0.646, \mathrm{p}<0.01)$ and $(\mathrm{r}=0.972, \mathrm{p}<0.01)$ respectively. In addition to that, there is a positive relationship between government spending and consumption $(r=0.628, p<0.01)$.

Table 10. Correlation coefficient among dependent and independent variables 1999-2014

\begin{tabular}{lcccccc}
\hline Variables & $\mathbf{1}$ & $\mathbf{2}$ & $\mathbf{3}$ & $\mathbf{4}$ & $\mathbf{5}$ & $\mathbf{6}$ \\
\hline Tax revenues & 1 & 0.120 & 0.422 & 0.262 & 0.249 & $\mathbf{- 0 . 7 5 2 * *}$ \\
GDP & & 1 & $\mathbf{0 . 6 4 6 * *}$ & $\mathbf{0 . 9 7 2 * *}$ & 0.232 & -0.460 \\
Government spending & & & 1 & $\mathbf{0 . 6 2 8}^{* *}$ & 0.088 & -0.482 \\
Consumption & & & 1 & 0.355 & $\mathbf{- 0 . 6 3 0}^{* *}$ \\
Investment & & & & 1 & -0.370 \\
Balance of Trade & & & & & & 1 \\
\hline
\end{tabular}

**. Correlation is significant at the 0.01 level (2-tailed).

Table 11 shows the influence of each of GDP, government spending, consumption, investment and balance of trade on tax revenues in Palestinian authority in time series between 1999-2014. The impact of balance of trade on tax revenues is empirically confirmed. The impact of these variables is negative on tax revenues within the time series. However, for the other independent variables there is no significant impact of these variables on tax revenues. Furthermore, equation (6) is proved that the negative impact of balance of trade on tax revenues is significant with value $\mathrm{p}$ - value less than 0.01 and with error 0.682 .

Table 11. The OLS summary statistics of the Null hypothesis (the interdependence between economies according to the TAX) in the period 1999-2014

\begin{tabular}{lccccc}
\hline Causal Relationship & Constant & Coefficient & F-Value & R Square & Sig. \\
\hline Tax revenues - GDP & 518.989 & 0.36 & 0.0206 & 0.14 & 0.657 \\
Tax revenues - GS & 212.668 & 0.276 & 3.029 & 0.178 & 0.104 \\
Tax revenues - C & 137.453 & 0.094 & 1.036 & 0.069 & 0.326 \\
Tax revenues - I & 306.687 & 0.357 & 0.927 & 0.062 & 0.352 \\
Tax revenues - BT & $\mathbf{- 1 1 1 0 . 8 6 7}$ & $\mathbf{- 0 . 6 7}$ & $\mathbf{1 8 . 2 6}$ & $\mathbf{0 . 5 3 5}$ & $\mathbf{0 . 0 0 1}$ \\
\hline
\end{tabular}

$$
T R_{p t}=-1110.867--0.67 B T_{p t}+0.682
$$

equation(6)

\subsection{Additional Evidence (Granger Causality Test)}

Table 12 uses Pairwise Granger causality test and shows the causality relationships between the variables of this study. the table shows that the Palestinian tax revenues does not Granger Cause the Palestinian GDP, government spending, consumption, investment and balance of trade, that value of the Alpha is more than 0.05. The empirical results of Pairwise Granger causality test are not complied with the previous literature mentioned in section 2 of this study.

Table 12. Results of Pairwise Granger causality tests

\begin{tabular}{lcc}
\hline The Null Hypothesis & F-Statistic & Alpha \\
\hline The Palestinian tax revenues does not Granger Cause the Palestinian GDP & 2.69971 & 0.1207 \\
The Palestinian GDP does not Granger Cause the Palestinian tax revenues & 0.31822 & 0.7353 \\
The Palestinian tax revenues does not Granger Cause the Palestinian GS & 1.06790 & 0.3836 \\
The Palestinian GS does not Granger Cause the Palestinian tax revenues & 0.03697 & 0.9638 \\
The Palestinian tax revenues does not Granger Cause the Palestinian Consumption & 3.58953 & 0.0714 \\
The Palestinian Consumption does not Granger Cause the Palestinian tax revenues & 0.30719 & 0.7429 \\
The Palestinian tax revenues does not Granger Cause the Palestinian investment & 0.17916 & 0.8389 \\
The Palestinian investment does not Granger Cause the Palestinian tax revenues & 1.95811 & 0.1968 \\
The Palestinian tax revenues does not Granger Cause the Palestinian Balance of Trade & 3.55139 & 0.0730 \\
The Palestinian Balance of Trade does not Granger Cause the Palestinian tax revenues & 0.10065 & 0.9053 \\
\hline
\end{tabular}




\section{Conclusion and Recommendations}

This paper based to investigate the causality relationship between tax revenues and GDP and its components in Palestinian authority during 1999-2014 i.e. government spending, consumption, investment and balance of trade. The result indicates that tax revenues does not Granger Cause the Palestinian GDP, government spending, consumption, investment and balance of trade. In overall period results confirmed that the balance of trade negatively effect on tax revenues on tax. Moreover, in each stage, the impact of macroeconomic variables on tax revenues was changing from one stage to another. This confirms that the modifications on tax code affect the tax revenues in Palestine. In addition, the political environment purported to boom-recession cycle during the period between "1999-2015". The period from 1999-2001, from 2004-2006 and 2009-2015 this periods had a relatively high growth rate in microeconomic factors and stability. However, the period from 2002-2004 and the period from 2006-2008 were recession periods.

Main finding in the first stage (1999-2007) shows that there is a positive impact of each of GDP, government spending and consumption on tax revenues, this result supported by, whereas there is a negative impact of balance of trade on tax revenues. In second stage, testing hypothesis empirically confirmed the positive effect of government spending on tax revenues. It's very important to note that the Palestinian economy characterized as stagflation economy in this period. Moreover, the results point out, that there is no significant impact of GDP and its components on tax revenues in third stage. The deferent results in each stage are related to many reasons such as instability in political environment and changing in income tax act.

Eventually, the researchers recommend: (1) the Palestinian authority should motivate investment conditions, (2) improve the tax collection instruments and decrease the tax invasion, especially, inner $\mathrm{C}$ areas in west bank which characterized as shadow economy. (3) Rationalize the government consumption spending and increase the government expenditure for the development. (4) Taxes should focus on products that use of high-income groups.

\section{References}

Agbeyegbe, T., Stotsky, G. J., \& Mariam, A. W. (2004). Trade liberalization, exchange rate changes, and tax revenue in sub-Saharan Africa. IMF Working Paper WP/04/178 Washington D.C: International Monetary Fund.

Al-Khulaifi, A. S. (2012). The Relationship between Government Revenue and Expenditure in Qatar: A Cointegration and Causality investigation. International Journal of Economics and Finance, 4(9). http://dx.doi.org/10.5539/ijef.v4n9p142

AL-Mahaeni, M. K. (2003). The role of tax in economic and social development process with practical cases in the comparative tax legislation. Damascus University Journal, 19(2), 255-315.

Aquash, S. J., \& Nadifon O. E. (2014). Tax Revenue Allocation and its Effect. Archives of Applied Science Research, 6(1), 199-208.

Brender, A., \& Navon, G. (2010). Predicting government tax revenues and analyzing forecast uncertainty. Israel Economic Review, 7(2), 81-111.

Canicio, D., \& Zachary, T. (2014). Causal Relationship between Government Tax Revenue Growth and Economic Growth: A Case of Zimbabwe (1980-2012). Journal of Economics and Sustainable Development, 5(17).

Chigbu, E. E., Akujuobi, L. E., \& Appah, E. (2012). An Empirical Study on the Causality between Economic Growth andTaxation in Nigeria. Current Research Journal of Economic Theory, 4(2), 29-38.

Elyasi, Y., \& Rahimi, M. (2012). The Causality between Government Revenue and Government Expenditure in Iran. International Journal of Economic Sciences and Applied Research, 5(1), 129-145.

Essays, U. K. (November 2013). The Factors Determine Tax Revenue In Malaysia Economics Essay. Retrieved from

http://www.ukessays.com/essays/economics/the-factors-determine-tax-revenue-in-malaysia-economics-essa y.php?cref $=1$

Gentry, W. M., \& Hubbard, R. G. (2004). Tax Policy and entry into Entrepreneurship. Retrieved from https://www0.gsb.columbia.edu/mygsb/faculty/research/pubfiles/571/Hubbard_tax_policy.pdf

Gordon, R. H. (1998). Can High Personal Tax Rates Encourage Entrepreneurial Activity. IMF Staff Papers, 45(1), 49-80. http://dx.doi.org/10.2307/3867329 
Hakim, T. A., \& Bujang, I. (2012). The Impact and Consequences of Tax Revenues' Components on Economic Indicators: Evidence from Panel Groups Data. INTECH Open Access Publisher. http://dx.doi.org/10.5772/48415

Hijazi, A. A. (2001). Tax systems between theory and practice. AL Dar AL Jamiaeah, Beirut.

Hussien, M. H. (2005). On the Causal Relationship between Government Expenditure and Tax Revenue in Pakistan. The Lahore Journal of Economics, 9(2), 105-117.

Li, K., \& Murphy, P. L. (2010). Tax Revenue Downturns: Anatomy and Links to Imports. International Monetary Fund. Retrieved from https://www.imf.org/external/pubs/ft/wp/2010/wp10138.pdf

Likhovski, A. (2010). Is Tax Law Culturally Specific? Lessons from the History of Income Tax Law in Mandatory Palestine. Theoretical Inquiries in Law, Forthcoming. http://dx.doi.org/10.2202/1565-3404.1257

Mahmood, H. (2013). Impact of FDI on Tax Revenues in Pakistan. Pakistan Journal of Commerce and Social Sciences, 7(1), 59-69.

MAS. (2015). Income Tax Code modifications- Aims and Expected Results. Session (4). Retrieved from http://www.mas.ps/files/server/20151506151202-1.pdf

Mashkoor, M., Yahya, S., \& Ali, S. A. (2010). Tax revenue and economic growth: An empirical analysis for Pakistan. World Applied Sciences Journal, 10(11), 1283-1289.

Mehrara, M., \& Rezaei, A. A. (2014). The Relationship between Government Revenue and Government Expenditure in Iran. International Journal of Academic Research in Business and Social Sciences, 4(3). http://dx.doi.org/10.6007/IJARBSS/v4-i3/687

Miki, B. (2011). The Effect of the VAT Rate Change on Aggregate Consumption and Economic Growth. CJEB Working Paper, no. 297.

Miswadeh, S. N., \& Al-Mofleh, K. M. M. (2015). The role of tax revenue in supplying General Budget with public revenues - a comparative study -in the period between (2006-2013). IUG Journal of Economics and Business, 23(2), 141-171.

Muibi, S. O., \& Sinbo, O. O. (2013). Macroeconomic Determinants of Tax Revenue in Nigeria (1970-2011). World Applied Sciences Journal, 28(1), 27-35.

Nanthakumar, L., Kogid, M., Sakami, M. N., \& Muhamad, S. (2011). Tax Revenue and Government Spending Constraints: Empirical Evidence from Malaysia. China-USA Business Review, 10(9), 779-784.

Owoye, O. (1994). The causal relationship between taxes and expenditures in the G7 countries: Cointegration and error-correction models. Applied Economics Letters, 2, 19-22. http://dx.doi.org/10.1080/135048595357744

Rahhal, A. I. (2014). The Reasons of Tax Evasion in Palestine: View of Tax Managers in Income Tax Department. International Journal of Economy Management and Social Sciences, 3(10), 556-561.

Sacky, J. A., \& Ejoh, N. O. (2014). Tax revenue allocation and its effects on consumption (VAT): A study of Calabar Municipal Council, Cross River State. Archives of Applied Science Research, 6(1), 199-208.

Slemrod, J. (2004). Are Corporate Tax Rates, or Countries, Converging? Journal of Public Economics, 88, 1169-1186. http://dx.doi.org/10.1016/S0047-2727(03)00061-6

Taha, R., \& Loganathan, N. (2008). Causality between tax revenue and government spending in Malaysia. The International Journal of Business and Finance Research, 7(2).

Tzougaz, J. (2013). Tax Revenue, Private Investment and Real Income in Greece: Evidence form Multivariate Cointegration and Causality Analysis. http://dx.doi.org/10.2139/ssrn.2296000

Zortuk, M., \& Uzgoren, N. (2008). The relationship Between the Taxation and Government Expenditure in Turkey- Bounds test Approach. Banks and Banks Systems, 3(1).

\section{Copyrights}

Copyright for this article is retained by the author(s), with first publication rights granted to the journal.

This is an open-access article distributed under the terms and conditions of the Creative Commons Attribution license (http://creativecommons.org/licenses/by/3.0/). 